Sosyal Bilimler Dergisi / Cilt: 16, Sayı 1, 2014, 101-128

\title{
Kültürel Bir Gösterge Olarak Gelenek ve Modernlik İkilemi: "Sıla" Televizyon Dizisi Örneği
}

DOI NO: 10.5578/JSS.7783

Devrim Özkan'1

\section{Özet}

Türk toplumu, kültürel ve toplumsal dönüşüm süreçlerinde, gelenekleri ile modern yaşamın getirmiş olduğu yaşam kalıpları arasına sıkışmıştır. Gelenekçi ve modernist olarak tanımlanabilecek iki farklı söylemin, kültürel kodlar üzerinden tartışılması ve toplumsal kökenlerine dair tartışmalara daha az rastlanması, dikkat çekici bir olgudur. Incelenmesi gereken bu söylemlerin içerikleri politik ve kültürel kökenlere sahiptir. Ayrıca, gelenekçi ve modernist olarak ayrllan bu iki söylem, medyada, farklı biçimlerde, sunulmaktadır. Çalışmamızda, 15.09.2006 tarihinde ATV'de yayınlanmaya başlayan, yapımcılı̆̆ını FM Yapım'ın üstlendiği, yönetmenliğini Gül Ŏguz'un yaptı̆̆l, senaryosu Sema Ergenekon ve Eylem Canpolat'a ait olan Sila adl dizi film incelenmektedir. Bu dizi film aracılı̆̆lyla oryantalist ve modernleşmeci söylemin çeşitli formları bizlere sunulmaktadır. Ortak belleğimizdeki karşıllklı bilgimizi derinden etkileyerek, oryantalist ve modernist bir içerik çerçevesinde inşa edilmesi Sıla dizinin, inceleme nesnesi olarak seçilmesine sebep olmuştur.

Anahtar kelimeler: Medya, Sıla (Dizi Film), Modernlik, Televizyon, İçerik Analizi, Kültürel Gösterge.

\footnotetext{
${ }^{1}$ Yrd. Doç. Dr., İzmir Katip Çelebi Üniversitesi, Sosyal ve Beşeri Bilimler Fakültesi, Medya ve İletişim Bölümü. ozkandev@hotmail.com
} 
D. Özkan / Kültürel Bir Gösterge Olarak Gelenek ve Modernlik İkilemi: "Sıla” Televizyon Dizisi

\title{
The Dilemma between Tradition and Modernity as a Cultural Indicator: The Case of "Sıla" TV Series
}

\begin{abstract}
Turkish society gets stuck in the dilemma between their traditions and the life patterns of modern life. It is also salient that the two different discourses as modernism and traditionalism have been discussed based on cultural codes; however, the discussions based on social principles have rarely been encountered. Two different contents of discourses that should be analysed have political and cultural roots. Furthermore, these two discourses as traditionalism and modernism are presented differently in the media. This study scrutinized Sila TV series which starts to be broadcasted on 15th, September, 2006 on ATV. The TV series was produced by FM Production, directed by Gül Oğuz, and written by Sema Ergenekon and Eylem Canpolat. The different forms of the orientalist and modernist discourse were presented to us with the mediator role of this $T V$ series. The reason why Sila $T V$ series were chosen as analysis object was that it was framed within an orientalist and a modernist content affecting our mutual knowledge in our collective conscience deeply.
\end{abstract}

Keywords: Media, Sila (TV Series), Modernity, Television, Content Analysis, Cultural Indicator.

\section{Giriş}

Modern toplumlarda, özneler arasında, daha önceki toplum yapılarına nazaran, son derece kompleks "karşılıklı bağlantı şebekeleri" (cross connected networks) mevcuttur. Bu nedenle, daha önceki dönemlerde işlevsel olan çeşitli iletişim yöntemleri, yerlerini yeni medya araçlarına birakmaktadır. Bu sayede, aynı toplumda var olan bireyler birbirlerinin ilgi ve problemlerine dair bilgilenmekte ve benzer konulara dair düşünerek tartışabilmektedir. Modern medya araçlarının en önemlilerinden bir olan televizyon vasıtasıyla sunulan eserler, kişilerin birbirlerinin beğenileri, kültürleri ve yaşam tarzlarına dair bilgi edinmelerini temin etmektedir. Ayrıca, özellikle televizyon dizileri vasıtasıyla, çeşitli yaşam tarzları idealize edilmekte ve kişiler kendi yaşam tarzlarını diğerlerininkiler ile karşılaştırarak değerlendirmektedir. Bunun yanı sıra, televizyon, iktidarın ideolojik bir aygitı olarak, kişi, grup ve komünitelerin manipüle edilerek yönlendirilmeleri için kullanılabilmektedir. $\mathrm{Bu}$ nedenle televizyon dizileri, bir toplumun kültürel yönelimlerinin yanı sıra, politik problemlerinin analiz edilmesi için önemli bir "kültürel gösterge" (cultural indicator) kaynağıdır. Diziler vasıtasıyla belirli dünya görüşü ve yaşam tarzlarına olumlu nitelikler atfedilirken, "ötekileştirilen" diğerlerine karşı eleştirel bir tutum takınılabilmektedir. Medyada nelerin hangi kültürel, tarihsel ve politik 
sebeplerden dolayı tasdik edildiği, gerek iletişim bilimleri, gerekse kültürel çalışmalar açısından önem arz eder. Özellikle modernlik problemi söz konusu olduğunda, "geç modernleşmiş," "geleneksel" ve "gelişmekte olan" ülke ve toplumlarda, televizyon dizilerindeki diyalogların içeriklerindeki temalar çeşitli ideoloji ve dünya görüşlerini yansıtmaktadır.

İletişim bilimleri disiplinler arası bir nitelik arz etmesinden dolayı, diğer bilim sahaları ile benzer temaları, kaynakları ve araştırma metotlarını paylaşır. Özellikle pek çok bilim sahasında uygulanan "içerik analizi yöntemi" (content analysis method) iletişim bilimleri araştırmaları için gerekli ve kullanışlıdır (Lombard, Snyder-Duch ve Bracken, 2002: 587). İçerik analizi medya araçları vasıtasıyla izleyicilere sunulan eserlerin dijital bir nitelik arz etmeye başlamasıyla, her geçen gün daha kullanışlı hale gelmektedir (Daniel ve King, 2010: 229; Riffe, Lacy ve Fico, 2005). Son yıllarda medyadaki söylem içeriklerinin nitelikli bir biçimde analiz edildiği çalışmalardaki artış dikkat çekicidir. Bu durum, çeşitli toplumsal, kültürel ve politik problemlerin medyadaki eserlerin içeriklerine, çeşitli şekillerde, yansımasından kaynaklanmaktadır.

Sila dizisinde, Türkiye'de, özellikle 1980'li y1llardan günümüze kadar, büyük bir hızla ve kontrolsüz bir biçimde gerçekleşen dönüşümlerin kültürel göstergeleri mevcuttur. Ağırlıklı olarak, toplumsal değer ölçütlerinde gerçekleşen bu dönüşümler, politik, toplumsal ve kültürel kodlar vasıtasıyla görünür hale gelmektedir. $\mathrm{Bu}$ çalışmadaki içerik analizi, televizyon vasitasıyla sunulan göstergelerin "kültürel göstergeler" olarak kabul edilmesinden hareketle gerçekleştirilmiştir. Sıla dizisindeki bu kültürel göstergelerde, Türk modernleşmesi bağlamında, hangi dünya görüşünün, kültürel kimliğin, değerlerin ve eylemlerin olumlandığı; hangi ikili karşıtlıkların anlatıdaki temel söylemleri yapılandırdığı; hangi karşıt karakterlerin, mekânların, eylemlerin bulunduğu ve hangi yaşam kalıplarının nasıl sunuldukları, "içerik analizi yöntemi" ile incelenmektedir.

Çağan'a (2006: 25) göre, “sanat eserleri, hiçbir zaman salt estetik, demokratik değişim araçları değildirler; aynı zamanda iktidar mücadelesini de içlerinde barındıran çok yönlü olgulardır." Sanat eserlerinin bu niteliği medya vasitasıyla sunulan eserler için de geçerlidir. Televizyon dizileri, eğlence programları ve haberler, nelerin güzel, doğru veya ideal olduğuna dair çok sayıda politik tartışmanın tarafı ve taşıyıcısı olabilmektedir. $\mathrm{Bu}$ nedenle medyada sunulan eserler politik içeriklerinin yanı sıra, sonucu oldukları tarihsel nedenlerden hareketle incelenmelidir. Bunun için, çalışmamızda Sıla dizisinin, estetik ve görsel özelliklerinden ziyade, içerdiği kültürel gösterge ve örtük mesajların ortaya çıkarılması amaçlanmaktadır. 


\section{Modernleşme ve Batılılaşmanın Türkiye'deki Alımlanışı}

Modernizmin düşünsel dayanakları, "gelenek" (tradition) ile arasında gerçekleşen çatışmalardan beslenir. Modernist bakış açıları için, geçmişin değerleri bugünün özgür bir biçimde inşa edilmesinin önündeki en büyük engeldir. Modernizm için, geleneğin verili değerlerden oluşması, modernitenin kurucu bir toplumsal rol verdiği öznenin, kendi değerlerini özgürce oluşturabilmesini engeller. $\mathrm{Bu}$ nedenle modernliğin, belirleyici özelliği (özellikle Fransa'daki modernleşme deneyiminde) kendisini gelenek karşıtlığıyla tanımlıyor olmasıdır. Zira modernliğin özgürlük söyleminden hareket ederek oluşturmuş olduğu ahlaksal değerler, geçmişle hesaplaşmasına dayanmaktadır. Fransız aydınlanma geleneğinin yıkıcı karakteri, verili değerleri gelişime engel olarak görülmesinden kaynaklanır. Fransız aydınlanmasının verili değerler ile karşıtlığı, radikal politik uygulama ve görüşler geliştirmesine neden olmuştur (McMahon, 2001: 189). $\mathrm{Bu}$ sayede, modern söylem tarafindan modern çağların öncesindeki geleneksel dönemler ve yaşam tarzları, "karanlık çă̆lar" (ya da ortaçağ karanlığı) biçiminde nitelendirilmiştir. Böylece kendisini "aydınlanma çă̆g" olarak niteleme olanağına kavuşan "aydınlanma ideolojisi," toplumsal hayatı biçimlendirebilmesini temin eden bir meşruluk zeminini elde etmiştir.

Aydınlanma geleneğinin gelenek karşıtlı̆̆ı, farklı zaman ve mekânlarda çeşitli politik ve kültürel problemlere neden olmuştur. Yıldırım (2008: 17-18), Tanzimat reformlarından itibaren ortaya çıkan çok sayıdaki politik ve kültürel değişimim, geleneksel toplumsal yapıların çözülmelerine neden olurken, yeni toplumsal ilişkilerin gelişmesine yol açtığına, ancak toplumsal hayatın sürdürülmesi için vazgeçilmez olan "ortak kültürel kodların" çözülmesine de sebebiyet verdiğine dikkat çeker. Toplumsal hayatın nasıl sürdürüleceğine dair "ifade edilmeyen" bir biçimde paylaşılan kültürel kodların çözülmesi, çok sayıda politik ve kültürel problemin ortaya çıkmasına neden olur. Batı Avrupa, Türkiye ile karşılaştırılacak olursa, modernleşme sürecini uzun bir süreçten geçerek tamamlamıştır. Düşünsel dayanakları on altıncı yüzyıla kadar götürülebilecek olan bu süreç, esas itibariyle on yedinci yüzyıldan itibaren başlamıştır. Türkiye'deyse modernleşme süreci, en fazla, yüz elli yıllık bir döneme yayılmıştır. Bu süreçte, gerek bürokrasi, gerekse toplum yeni gelişmelere hızlı bir biçimde adapte olmaya çalışmıştır. Lewis (1980: 33), Osmanlı İmparatorluğu'ndan Türkiye Cumhuriyeti'ne geçiş sürecinde Osmanlı bürokrasisinin, kısa bir sürede yeni sisteme adapte olarak, önemli katkılarda bulunduğunu belirtir. Toplumun ve bürokrasinin modernleşme süreçlerine adapte olma çabalarına karş1, Türkiye'nin yaşamış olduğu modernleşme sürecinin, Bat1 Avrupa'nın yaşamış olduğu beş yüzyıllık süreç ile karşılaştırıldığında son derece kısa 
olması, medyada yer alan eserlere de yansıyan, çeşitli politik ve kültürel problemlere yol açmıştır.

Türk modernleşmesi sürecinde, "yabancl" bir olgu olarak değerlendirilen modernlik, devlet mekanizmasının gelişmesini temin edeceğine inanılarak gerçekleştirilmeye çalışıldığından, toplum tarafından yeteri kadar kabul görmemiştir. Bu sebepten dolayı, Türkiye'de yaşanan toplumsal dönüşüm süreçleri, çok sayıda problem tam bir çözüme kavuşturulmadan aşılmaya çalışılmıştır. Zira Türk modernleşmesi, üst belirlenimler ve kurumsal yaptırımlar vasitasıla, geleneksel toplum yapılarına rağmen uygulanmaya çalışılmış bir proje olarak geliştirilmiştir. Bağlı (2004: 29-30), Türkiye'de, iç dinamiklerden daha çok dış dinamikler vasıtasıyla gerçekleştirilmeye çalışılan bir değişim politikasının egemen olduğuna dikkat çeker. Bu durum toplumsal aktörler arasındaki iletişim ve etkileşimin patolojik nitelikler arz etmesine yol açmaktadır. Politik iletişim süreçlerinin patolojikleşmesi, gerek toplumsal dönüşümler için gerekli olan modernleşmeyi hayata geçirmeye çalışanların, gerekse geleneksel yaşamı sürdürmeye uğraşanların, "karşılıklı anlamayı" (mutual understanding) yeteri kadar toplumsal etkileşim süreçlerinin belirleyici faktörlerinden biri haline getirmemelerinden kaynaklanır.

Tüm bunların yanı sıra, Türk modernleşmesinin önemli aktörlerinin, dünyada artık geçerliliğini yitirdiğini düşündükleri pek çok değer yargısıyla donanmış bir toplumu, çağdaş bir uygarlık seviyesine taşımak gibi bir zorunlulukla karşı karşıya bulunduklarına inanmaları, gerek politik, gerekse toplumsal açıdan önemli etkilere sahiptir. Ayrıca, modernist politik öznelerin, gerçekleştirmeye çalıştıkları dönüşüm için son derece kısıtlı bir zaman aralığına sahip oldukları unutulmamalıdır. Ancak Türkiye'deki modernleşme sürecinin eleştirel bir bakış açısıyla değerlendirilerek revize edilmesi gerektiği de kuşkuya yer bırakmayacak bir olgudur. Türk modernleşmesi, karşı karşıya kaldığı "kültürel kodlar problemi" karşısında eleştirel bir bakış açısına ihtiyaç duymaktadır.

Şüphesiz ki, Türkiye'de on dokuzuncu yüzyılın sonlarından itibaren gerek politikanın, gerekse toplumun öncelikli problemlerinden bir halene gelen modernleşme (ya da batılılaşma) süreçlerinde, çeşitli ekonomik ve politik atılımlar gerçekleştirilmiştir. Özellikle, kültür sahasında dikkate değer çalışmaların mevcut olduğu aşikârdır. $\mathrm{Bu}$ önemli atılımların yanı sıra, Türkiye'de gerçekleşen modernleşme süreci, toplumun çift kutuplu bir görünüm arz etmesine sebep olmuştur. $\mathrm{Bu}$ çift kutupluluk, Türk modernistlerinin feyz aldıkları on dokuzuncu yüzyıldaki modernist yaklaşımların, pozitivizmin etkisi altında gelişimlerini sürdürmüş olmalarından kaynaklanır. Bu noktada pozitivizmin toplumbilimleri alanında 
bir toplumsal mühendislik çabasına paralel olarak ilerlediği unutulmamalıdır. Modernliğin gereklilikleri toplumsal yapının tamamen yeniden tasarlanmasını gerektirir. Geleneksel toplum yapılarında ise yerel nitelikler belirleyicidir. Modernlik ise, yerelliklerden ziyade, yekpare bir toplumsal yapının inşasını gerektirir. Modernlik için toplumu oluşturan tüm

öznelerin "eşgüdümlü" (coordinative) eylemlerde bulunabilmeleri idari mekanizmanın işleyişi açısından son derece önemlidir.

Toplumun modernliğin gerekliliklerini temin etmek maksadıyla "rasyonel" bir biçimde yeniden tasarlanması, kimi zaman ve mekânlarda, inşa edici politik öznenin, nesnesini ötekileştirmesine neden olabilmektedir. Örneğin, bu durum, Fransız modernleşme deneyimi için geçerlidir. Yine bu noktada, dikkat edilmesi gereken bir başka husus, Fransız Jakobenlerinin dünyadaki tüm diğer modernist eğilimler gibi, Türk modernleşmesini de, derinden etkilediğidir. Fransız Jakobenizmi, çoğulculuğu benimsemiş İngiliz liberalizmiyle önemli farklılıklara sahiptir. İngiliz liberalleri toplumsal dönüşümün, toplumsal bir gelişme sürecinin neticesi olarak gerçekleşebileceğini düşünür. Fransız Jakobenleri ise, belirli bir elitin topluma müdahale etmesi sonucunda modernleşmenin sağlanabileceğine inanır. Bunun gerçekleşebilmesi için toplumun verili değerlerini oluşturan dinsel ve kültürel motifler, kamusal alandan geri çekilmelidir. İşte bu noktada Fransız ve Türk laikliği arasındaki en önemli benzerlik ortaya çıkar. "Fransiz ve Türk laikliği arasındaki tek benzerlik kamu alanından dinin çekilmesi konusundadır" (Göle, 2000: 100). Dinsel ve kültürel motiflerin kamu alanının dışına itilmesi "laik" ve "İslamcı" olarak ayrışan iki toplumsal tabaka arasında pek çok gerginliğin ortaya çıkmasına sebep olmuştur. Köker (2004), benzer bir yaklaşımla, modern batı toplumlarında temin edilmeye çalışılan çoğulcu uygulamalara yabancı olan Türk modernleşme deneyiminin, sınıfsız ve tek biçimli bir toplum tasarımına bağlı olduğundan, toplumu ve politikayı sınırlandıran eğilimlere sahip olduğunu düşünür. Tek biçimli bir toplum tasarımı ile politikaların belirlendiği bir sistemde keskin ayrışmaların yaşanması kaçınılmazdır.

Mardin (1969: 280), Türkiye'de devletin özellikle ekonomik sahada, başat belirleyici olduğuna dikkat çeker. $\mathrm{Bu}$ durum Türk toplumunda politikanın, sadece, devlete egemen olmak için gerçekleştirilen bir etkinliğe dönüşmesine neden olmuştur. Sivil toplumun mekanik bir biçimde işleyen bir olgu olarak ele alınmasının nedeni, Türk entelektüel ve bürokratlarının, kendi egemenliklerini tesis etmek maksadi ile toplumu tasarlamaya çalışmalarıdır. Ayrıca Türk devriminin kültür ve değer merkezli bir karaktere sahip olması, bir kültürel elitin ortaya çıkasına da neden olmuştur (Mardin, 1971: 209-210). Gerçekten de, bir modernleşme projesi olan ve 
Fransız aydınlanması ile ilerleme düşüncesinden derin izler taşıyan Cumhuriyet de, akla ve bilimsel temellere dayalı "dünyevi toplum" (secular society) kavrayışı1nı benimsemiştir.

Türk modernizminin korucu aklı, pozitivizmin etkisi altında biçimlenmiştir. Pozitivizmin hakikat kavrayışının politikadaki yansıması, tek biçimli toplumsal yapının inşasının amaçlanmasıdır. $\mathrm{Bu}$ akıl kendi epistemolojisini, Türk modernizminin yönetim ideolojisinde egemen kılmış ve toplumsal sistem pozitivist bir yönetim anlayışı ile inşa edilmiştir. Türk modernistleri Osmanlı İmparatorluğu'nun gerileme sürecine girmesiyle dile getirilmeye başlanan, dinin toplumsal gelişmeye ve ilerlemeye engel teşkil ettiği tezini, yeni toplumsal yapının oluşmasında bir başlangıç noktası olarak kullanılmıştır. $\mathrm{Bu}$ sebeple, bürokrasi, ilerleme zihniyetine sahip bir modernleşme tasarımıyla hareket ederek, geleneği temsil ettiğine inandığı Osmanlı toplum ve düşünce yapısını, modern yaşamın ve dünya tasarımının hayata geçirilmesi önünde önemli bir engel olarak görmüştür. Türk modernistlerinin, bu engeli ortadan kaldırmaya yönelik attığı adımlardan belki de en önemlisi, Osmanlı döneminin düşünsel yapısını ve sembollerini ortadan kaldırmak olmuştur. Ancak, Yıldırım'ın (2012: 2-3) belirttiği gibi, Türk modernleşmesi, Osmanlı İmparatorluğu'nun "patrimonyal" (patrimonial) yönetim anlayışını devam ettirmiştir. "Neo-patrimonyalizm" (neopatrimonialism) kavramsallaştırmasıyla, Türkiye'de gerçekleşen süreç, modernleşmeden daha çok modernleşmenin "tahrif edilmesi" ile açıklamaktadır. Yıldırım'a (2012: 3) göre modernleşmeyi temin edeceğini iddia eden kesimler, "patrimonyal" yönetimin kendilerine sağladığ 1 avantajlardan vazgeçmemiş ve toplumsal taban ile diyalojik bir ilişkiye dayanmayan bir politik ve kültürel sistem inşa etmiştir.

Modernleşmeyi yeni bir toplumsal gelişme süreci için, bir "milat" olarak benimseyen bürokrasi, kültürel kopuş teziyle hareket ederek, Osmanlı tarihini ve yaşam tarzını temsil eden sembolleri bilinçaltına atarak unutmaya; oluşturduğu tarih yazınında Osmanlı dönemini, adeta hiç yaşanmamış bir dönem olarak göstermeye çalışmıştır. Ayrıca Cumhuriyet döneminde sadece toplumsal hafizanın silinmesiyle sinırlı kalmayan uygulamalar gerçekleştirilmiştir. Burada güdülen amaç, Batı olarak işaretlenen ve çağdaş dünya değerleriyle hareket eden bir toplum yaratmak olmuştur (Kahraman, 2002: 155). Gerçekleştirilen dil devrimi, hem Osmanlıdan kültürel bir kopuşu ifade etmiş, hem de yeni bir zihinsel dünya yaratmak amacıyla yeni düşünme kodlarının oluşmasına yol açmıştır.

Toplumun dinden ve gelenekten tümüyle arındırılması ve geleneksel sembollerin toplumsal yaşamdan uzaklaştırılması ile toplumsal yaşamın dünyevileşmesi temin edilmeye çalışılmıştır. Ayrıca, dünyevi anlayışa uygun yeni bir kimliğin ve toplumsal bağların tesis edilmesine çalışılırken, 
ilerleme düşüncesine paralel yeni bir zaman formunun inşa edilmesine dayalı, yeni bir dil ve kültürün oluşturulması amaçlanmıştır. Zira Türk modernistleri Osmanlı İmparatorluğu'ndan sonra yeni uluslararası koşullar altında olduklarının bilincine sahiptiler ve yeni gelişmelere kısa sürede uyum sağlamak zorunda olduklarından, kapsamlı atılımlarda bulunmaları gerektiğine inanıyorlardı (Lewis, 1980: 34-35).

Geleneksel bir kültürden, modern bir yaşam tarzına doğru gerçekleşen toplumsal dönüşümler, Türk toplumunun yeni modern kültür değerlerini benimsemeye çalışmasına neden olmuştur. Keskin bir kırılma yaşayan toplumsal tabakalar, ortaya çıkan yeni değerler karşısında, birbirinden son derece farklı tepkiler göstermiştir. Modern değerlere karş1 çıkarak, geleneksel değerlere tutunmaya çalışan toplumun bir bölümü, karş1 çıkışlarını keskinleştirmiş ve radikalleşmiştir. Böylece, Doğu'da Batı karşıtlığı üzerinden kendisini tanımlayan bir düşünüş tarzı ortaya ç1kabilmiştir. Kömeçoğlu bu durumu, "modernlikle bir sentez kuramayan ve kendi sözde inancının özündeki birliği elden kaçıran bir grubun aslında kendi kendisini de yok eden kolektif nevroz vakası" olarak tanımlamaktadir (Kömeçoğlu, 2002: 35). Bu tarz bir nevroz vakasının Türkiye'de gerçekleşmiş olması, Türk modernleşme projesinin, "devleti yönetenler" ile "yönetilenler" arasında derin bir uçurumun oluşmasına sebebiyet vermesiyle açıllanabilir.

Tüm bunlardan dolayı, Türk politikasında, laiklik ile demokrasi arasında şiddetli bir gerilim ortaya çıkmıştır. Türk modernistleri, demokrasinin egemen olduğu bir kamusal alanda, çoğunluğun ilgi ve çıkarlarının belirleyici olmasının, toplumsal istikrar için tehlike arz ettiğini düşünmektedir. Bu sebepten dolayı İslami değerlerin kamusal alanda temsil edilmesi politik bir problem olarak karşımıza çıkmaktadır. Dolayısıyla politik çatışma kültürel kodlar etrafında gerçekleşmektedir. Bu durumu Göle (2000: 67) şu şekilde açıklar: "Yaşam tarzlarında ve estetik değerlerdeki... değişim, Íslami olandan Batılı olana bir medeniyet dönüşümünü çerçevelediği için masum ve değer yargılarından arınmış değildir. Toplumsal bir belirleyici olarak zevkler, kültürel ayrıcalıkları ve sinıflar arasındaki sosyal tabakalaşmayı oluşturmaktadır. Böylece Batıcılar ve muhafazakârlar arasındaki güç mücadelesi, kültürel kodlar ve yaşam tarzlarıyla tanımlanmaktadır."

$\mathrm{Bu}$ söylenilenlerden de anlaşılacağı üzere, yaşanan toplumsal dönüşümün, iktisadi ve sınıfsal uğraklar üzerinden değil, fakat kültürel kodlara yapılan birbirinden farklı vurgular vasıtasıyla gerçekleştiriliyor olması, Türk politikasındaki en büyük problemlerden biridir. Bürokratik kökenden gelen Türk modernistleri, "projeci" bir yaklaşım sergilemiştir. Bu projeci yaklaşım kendisini eğitim projelerinde açığa vurur. Eğitim kurumları 
iktisadi ve toplumsal alt yapı çalışmaları ile desteklenmeden geliştirilmeye çalışılmıştır. Toplumsal sınıfların oluşumu ve iktisadi kurumsallaşmalar yeteri kadar geliştirilmeden, sadece eğitim kurumlarına ağırlık verilerek toplumsal dönüşüm sağlanmaya çalışılmıştır. Bunun sebebi Türk modernistlerinin batılılı̆̆ "alımlama" (reception) tarzında çeşitli problemlerin mevcut olmasıdır. Batılılı̆ğn bu alımlanış tarzı, toplumun büyük bir kesiminin ötekileştirilmesine sebep olmuştur. Zira Türk modernistleri, modernizmi bir tür kültürlenme projesi olarak ele alır. Modernliğin, yerli kültürel kimlikleri dışlayan bir proje olarak ele alınması, Türk modernleşmesinin en önemli özelliklerinden biridir. Böylelikle sınırlayıcı bir zihniyetin politik ve kültürel alanda egemen hale gelmesi mümkün olabilmektedir.

Avrupa'da, modernleşme toplumun sahip olduğu iç dinamiklerin işleyişiyle gerçekleştirilen bir sürece tekabül etmiştir. Bu dönüşüm süreci boyunca iktisadi, kültürel ve politik dönüşümler birbiriyle paralel olarak gerçekleşmiştir. Türkiye'de ise modernleşme en başından itibaren bir batılılaşma projesi olarak ele alınmıştır. Dolayısıyla, kültürel iç dinamikler göz ardı edilmiştir. Bu durum, pek çok toplumsal neticeye yol açmıştır. Toplumda "kültür merkezli" modernleşme projesine karş1 kuvvetli bir tepkinin oluşması bunların en önemlilerinden biridir. Bu tepkinin sebebi, toplumun geniş kesimlerinin kendilerini, inşa edilmiş kültürel hiyerarşi cetvelinde en aşağıda görüyor olmalarıdır. Diğer yandan, modern değerler vasıtası ile kalkınmanın sağlanabileceğine inanan kesimin, modernliğin kültürel kodlarıyla kendisini ifade etmesiyle, iki kesim arasındaki yabancılaşma, belirgin bir biçimde, artmaktadır.

\section{Analizi}

2. Modernist İçeriklerinin Taşıyıcısı Olarak "Sıla" Dizisi ve

Günümüzde medya, insanların yaşam evrenlerinde geniş bir sahayı kapsamaktadır. Zira kişi, medyadan, gündelik yaşamda edindiği bilgilerin önemli bir bölümünü elde eder. Kişinin bilgi edindiği araçların en önemlilerinden biri televizyondur. Günümüzde bir kişi, eğer ki dünyaya ve insanlara dair bir bilgi edinmek istiyorsa, yapmas1 gereken fiillerden biri televizyonunu açmaktır. Böylelikle televizyon, hem kişilerin toplumsal yaşama evrenleri hakkında bilgilenmesini sağlamakta, hem de günlük yaşama streslerini üzerlerinden atmalarını temin etmektedir. Televizyonun vazgeçilmez bir araç haline gelmiş olması hem bilgilendirme, hem de eğlendirme işlevlerini aynı anda yerine getirmesinden kaynaklanır. Kişi, televizyonla karşı karşıya kaldığı tüm süreçlerden, yoğun biçimde etkilenmektedir. Hatta yaşama evrenini paylaştığ 1 diğer insanların gündemlerinin de sürekli olarak televizyon tarafindan belirlendiği 
düşünülecek olursa, televizyonla karşı karşıya kalmadığı zamanlarda dahi (toplumsal gündemi televizyon belirlediğinden dolayı), televizyonun etkilerine maruz kaldığı iddia edilebilir.

\subsection{Analizin Nitelikleri}

\subsubsection{Analizin Amacr ve Ehemmiyeti}

Televizyon vasıtasıyla, kişi dünyanın çeşitli mekânlarından binlerce konu hakkında bilgi edinebilmektedir. Fakat bir olay, kişi veya mekân hakkında malumat sahibi olmak ile belirli bir konu hakkında bilgi sahibi olmak arasında önemli bir farkın bulunduğu aşikârdır. Televizyon aracılığıyla maruz kalınan malumatların gelip geçiciliği, kolektif belleği olumsuz etkilemektedir. Bu sebeplerden dolay1 Postman (2004: 153), Amerikan toplumunun yoğun bir bellek kaybına uğradığından bahseder. Ona göre, televizyon aracıllğıyla içinde bulunduğu yirmi dört saatlik zaman dilimi hakkında her türlü malumata sahip olan Amerikalıların, ülkelerinin son atmış yılı hakkındaki bilgileri son derece sınırlıdır.

Baudrillard için (2004), televizyonun toplumsal bellek üzerindeki olumsuz etkileri son derece önemlidir. Zira bireyler gün boyunca bir malumat bombardımana maruz kalmaktadır. Bu malumat bombardımanının her gün tekrarlanıyor olması, bireylerin her gün belleklerini yenilemelerine yol açmaktadır. Kendisini sürekli olarak tekrarlayan bu sürecin sonucunda edinilen her türlü malumat, anlık alımlamaya dönüşerek anlamını yitirmekte ve tarihsel birikimin nesnesi olmaktan ziyade "malumat çöplügüune" dönüşmektedir. Bunun sebebi malumatlar arasından seçim yapılabilmesine olanak kalmamış olmasıdır. "Televizyonun amacı, dünyayı enformasyon [malumat] olarak üretmek ve bu enformasyona bir anlam kazandırmaktır" (Baudrillard, 2004: 140). Bu sayede, kabul edilebilir olan ile kabul edilemez olan birbirine karışabilmektedir. $\mathrm{Bu}$ bağlamda televizyonun toplumları tarihsizleşmesindeki katkısı göz ardı edilemez bir gerçek olarak karşımızda durmaktadır.

Özellikle son on yıllık dönemde, Türk televizyonlarında yoğun bir ilgi gören televizyon dizilerinin, yukarıda ana hatları çizilen "enfrastrüktür" (infrastructure) çerçevesinde değerlendirilmesi gerekir. Televizyonun kolektif bellek üzerinde olumsuz bir etkiye sahip olduğu aşikârdır. Bunun yanı sıra, Türkiye'de yaşanan modernleşme sürecinin bir sonucu olarak yaygın bir etkiye sahip olan "oryantalist" ve "modernist" söylem içerikleri, televizyonun olumsuz etkileriyle sentezlenerek, kimi televizyon dizilerinde ifadesini bulmaktadır. Hiç kuşkusuz ki, bu dizilerin en etkili ve önemli olanlarından birisi, Slla dizisidir. Bu dizi aracılı̆̆ıla "oryantalist" ve "modernist" söylem içeriklerinin çeşitli formları sunulmaktadır. Üstelik Sıla 
dizisinin etkisi sadece dizinin yayınlandığı saatlerle sınırlı bir etkiye sahip değildir. Dizideki diyalogların içeriği, oyuncularının medyatik karakterleri sayesinde magazin programlarında da sıklıkla karşımıza çıkmaktadır. Medyada çeşitli tarzlarda tekrarlanıyor olmasından dolayı, Sıla dizisinin kolektif bellek üzerinde önemli bir etkisi mevcuttur. Artık doğuya dair bilgiler bu dizi vasitasıyla elde edilmektedir. Toplumsal belleğimizdeki bilgi stokumuz üzerinde son derece yoğun bir etkiye sahip olması ve sunmuş olduğu bu bilgileri "oryantalist" ve "modernist" yaklaşımı temsil eden içerikleri barındırması, Sıla dizinin önemli bir inceleme konusu olarak seçilmesine sebep olmuştur. Bu sayede toplumun yapısını oluşturan başlıca gösterge ve problemlerin tespiti amaçlanmıştır.

Kültürel göstergeler toplumsal yapının analizi açısından büyük önem arz eder. Kültürü oluşturan tüm ögeler tarihsel bir sürecin birer neticesi biçiminde ortaya çıkarlar. Çağımızda medya kültürel göstergelerin dolaşımda olduğu en önemli vasıtalardan biridir. Bir toplumun temel problemlerinin, kaygılarının ve niteliklerinin ortaya çıkarılıp analiz edilmesinde medyada yer alan eserler, önemli bir veri (politik ve kültürel gösterge) kaynağıdır. Kişiler birbirleriyle medya yer alan eserlere dair birlikte düşünerek iletişimde bulunur. $\mathrm{Bu}$ sayede çeşitli problemlere dair ortak kanıların oluşması temin edilir. Tartışma, uzlaşma ve ortak kanıların oluşumu, birbirlerinden ayrılmayacak bir biçimde kamusal alandaki çeşitli diyaloglar vasitasıyla elde edilir. Bu nedenle neyin, ne şekilde ve hangi nedenler ile tartışıldığ 1 ve medya araçlarındaki eserlerde konu edildiği önem arz eder.

Sila dizisi bir yayınlandığı dönemde gerek kamuoyundaki, gerekse medyadaki tartışmaların önemli bir gündem maddesi haline gelmiştir. Türkiye'nin çeşitli politik, tarihsel ve kültürel problemleri S1la dizisinin, kamusal tartışmalara konu edilmesinde etkilidir. Bu nedenle, Sila dizisinin içeriğinin analiz edilmesi, hem tarihsel arka planın medyada yer alan eserlerin takip edilirliğinde ne derece etkili olduğunun tespiti, hem de Türkiye'de toplumsal problemlerin medyaya ne şekilde yansıdığının ortaya koyulması açısından önemlidir. Bu sayede bir yandan politik problemlerin, diğer yanda çözüme kavuşturulmamış kültürel problemlerin medyaya nasıl yansıdığ incelenebilir

\subsubsection{Analizin Sinırlılıklarl}

Analizde dizinin genel çerçevesinin çizildiği ilk bölümlerine odaklanılmıştır. Özellikle dizinin ikinci sezonundan sonra, dizinin popülerliğinden istifade edilmek amaçlandığından, benzer temalar sürekli tekrarlanmıştır. $\mathrm{Bu}$ nedenle dizinin ilk bölümleri en önemli veri kaynağını olma niteliğine sahiptir. Zira ilk bölümlerde, dizinin temel problemleri 
ortaya koyularak, izlenilirliğini sağlanmıştır. Ayrıca ilk bölümlerdeki temalardan dolayı, dizinin sonraki bölümleri izlenmeye devam etmiştir. İlk bölümlerde dizinin kahramanları arasında geçen diyaloglarda dizinin temel problemi oluşturularak, izleyiciye bir çerçeve çizilmiştir. Ancak diğer bölümlerinde tali sayılabilecek başka temalar geliştirilerek izleyicinin diziden kopmaması temin edilmeye çalışılmıştır. Analizin kültürel gösterge olarak nitelenen medyadaki bir eser ile sınırlanarak gerçekleştirilmiş olması, çok sayıda faktörü içeren kültür dünyası ile ilgili bir araştırma için en önemli sinirliliktır.

\subsubsection{Analizin Yöntemi}

$\mathrm{Bu}$ analizde Sila dizisindeki temel kültürel göstergelerin ve toplumsal problemlerin tespiti için içerik analizi yöntemi kullanılmışıı. Sila dizisinin içeriğindeki gelenek ile modernlik karşıtllı̆̆ının analizinde Bilgin'in (2000) İçerik Analizi adlı eserinde genel çerçevesini çizdiği kategoriler kullanılmıştır. Özellikle "eleştirel söylem analizi" (critical discourse analysis) çalışmaları, (1) politik söylem, (2) ideoloji, (3) rrkçılık, (4) ekonomik söylem, (5) reklam ve tanıtım söylemi, (6) medya dili, (7) toplumsal cinsiyet, (8) kurumsal söylem, (9) eğitim ve (10) edebiyat, başlıkları altında toplanmaktadır (Blommaert \& Bulcaen: 2000: 450-451). Bu çerçevede, çalışmamızda, benzer bir biçimde, medya dilinin biçimlendiği bir mecra olarak Sila dizisindeki önemli göstergelerin ve kodların nelerden oluştuğuna dair sorulara "içerik analizi yöntemi" ile cevap aranmaktadır. Sıla dizisinin söyleminin ana çerçevesinin biçimlendiği ilk bölümlerden diyaloglar incelenmektedir. $\mathrm{Bu}$ bölümlerdeki göstergelere, modernlik bağlamında, hangi söylemsel veya ideolojik sistemlerin anlam verdiği ve Sila dizisi aracılığıyla iletilen, tercihli anlatı biçiminin sosyokültürel ve ideolojik anlamları, açığa çıkarılmaya çalışılmaktadır. Modern sosyal teoride, çoğu zaman, söylem ile ideoloji kavramları birbirlerinin yerine kullanılabilmektedir (Purvis ve Hunt, 1993: 473). Bu çerçevede öncelikle dizide iletilen mesajların ideolojik tarihsel ve kültürel arka planı ortaya konulmaktadır. Daha sonra ki aşamada ise "söylenen şeye ilişkin kategoriler" ve "söyleme tarzlyla ilgili kategoriler" belirlenmektedir (Bilgin, 2000: 10). Bu iki kategorinin alt kategorileri tespit edildikten sonra mesajların bu kategorilere tekabül edip etmediği irdelenmektedir. 


\section{Elde Edilen Bulgular}

\subsection{Sıla Dizisi'nin Enfrastrüktürünün ve Başlıca Temalarının Biçimlendiği Anlatım Süreci \\ Stla dizisinin birinci bölümü, Sıla'nın (Cansu Dere) gündelik} hayatına dair tasvirler ile başlar. Sıla evlatlık olarak verildiği bir aile tarafından yetiştirilmiştir. İstanbul'da hayatını sürdüren Sıla, kendisini evlat edinen ailenin zenginliği sayesinde sahip olduğu modern hayatın tüm imkânlarından istifade etmektedir. Ayrıca, Sıla esas ailesinin hayatta olmadığına da inandırılmıştır. Ancak, biranda hayatı esas ailesi ile kesişir. Modern hayatın ve kentin gerekliliklerine göre yetiştirilmiş olan Sıla, esas ailesinin gelenekleri ile karşılaşınca büyük bir karmaşaya sürüklenir. Babası (Menderes Samancilar) Sila'yı, kendileriyle Mardin'e gelmeye ikna etmeye çalışır. Abisi Azad (Cemal Toktaş) annesinin Sıla'yı görmek istediğini ve ölmek üzere olduğunu söyler. Aslında büyük bir problem ile karşı karşıya olan babası ve abisi, Sıla'yı berdel karşı1ığında evlendirmek istemektedir. Bu sayede ortaya çıkabilecek bir kan davasına engel olmayı arzulamaktadırlar.

Annesini görmeyi arzulayan Sıla, geleneklerin yaşama egemen olduğu Mardin'de yaşayabileceği muhtemel olayları tasavvur edebilecek bilgiden yoksundur. Esas ailesinin, kendisinden habersizce onu evlendirmeye çalışacakları aklına gelmez. Oysaki ailesi Boran'la (Mehmet Akif Alakurt) Sıla'yı evlendirmeyi planlamaktadır. Boran Genco aşiretinin ağasıdır. Ailesi, Azad'ın işlediği suçun cezasını, bir biçimde Sıla'nın göğüslemesini talep etmektedir. Boran'ın kız kardeşi Narin'i (Boncuk Y1lmaz) kaçıran Azad'ın hayatta kalması S1la'ya bağlıdır. Geleneksel dünyanın dayattığı kuralların hükmüne tabi hale gelen Sıla için, esas ailesi ile tanışmanın mutluluğu kısa sürer.

Dizinin bu aşamasındaki yaşama evreninin temsilleri son derece önemlidir. Dizinin geçtiği mekânda geleneksel yaşam kalıpları toplumun tüm üyeleri üzerinde belirleyicidir. Bu mekânda, mimariden giyim tarzlarına kadar, her alanda geleneksellik belirleyiciliğini göstermektedir. Geleneğin başat güç olarak betimlendiği dizide, işlenen "kanun tanımaz gelenekler" ve "geleneklere rağmen yaşama savaşı veren aşk öyküleri" temaları, hikâyenin en önemli iki dayanak noktasını teşkil eder. Ayrıca modern bir yaşamı arzulayan Sıla ve gelenekleriyle kalbinin arasında sıkışıp kalmış olan Boran'ın trajik durumu, bir başka tema olarak sunulur.

Dizinin ikinci ve üçüncü bölümleri, gelenekleri ile kendi arzuları arasındaki ikileme sıkışıp kalan dizi kahramanlarının hayatlarına dair betimlemeler ile devam eder (Sıla, 2006a; 2006b). Gerçekten de, dizi boyunca, insanın yaşamının kendi belirlenimlerine tabi olmadığı, fakat gelenekler ve diğer kişilerin ilgi ve ihtiyaçlarıyla biçimlendiği bir yaşam dünyası betimlenir. Azat, Sıla'yı Boran ağa ile evlendirilerek, kendi 
problemlerinden kurtulmaya çalışır. Sıla, ilk defa deneyimlediği geleneksel yaşam kalıplarının baskılarına dayanamayarak Boran ile evlenmek zorunda kalır. Sıla'nın kendisi ile evlenmeyi istemediğini düğünden sonra öğrenen Boran, çok fazla üzülerek öfkelenir. Gelgelelim, hem Sıla, hem de Boran, geri dönüşü olmayan bir yolda olduklarını düşünürler. Yaşamları gelenekler tarafindan belirlenen bu iki genç, bir parçası oldukları komüniteleri karşısında kendilerini güçsüz hissederler.

Geleneksel yaşam dünyasında yaşamını sürdüremeyeceğine ikna olan Sıla, kaçamaktan başka çaresinin olmadığını düşünür. Sıla kaçtıktan hemen sonra, berdel aşiret tarafindan bozulur. Berdelin bozulmasıyla Narin ve Azad'ın ölüm kararları da verilmiş olur. Aile üyeleri Sıla'nın peşine düşerler. Gelenekler gereği Sıla, Azad ve Narin'in öldürülmesi gerekmektedir. Boran ise herkesten önce Sıla'ya ulaşarak, muhtemel bir cinayete engel olmaya çalışır. Sıla'ya ulaşmaya çalışanlar arsında bir tür yarış başlar. Boran ile aşiret liderliği için mücadele eden Cihan (Devrim Saltoğlu), Sıla'yı ilk ulaşan kişi olur. Sıla eve geri dönmek zorunda kalır. Boran, Narin ve Azad'ın hayatının ona bağlı olduğunu söyler ve aralarında şu diyalog gerçekleşir:

“Sıla - Neden bunu yaptın? Neden benim için yalan söyledin?

Boran - Senin için değil, Azad'la Narin 'in yaşaması için yalan söyledim. Bu evlilikteki gibi.

Sila - Şu an buradayım ama durduramayacaksın beni. Bugün olmazsa yarın kaçacağım. On yıl sonra olsa da kaçacă̆ım, bu evde seninle kalmayacă̆ım. Boran - Ne zaman ki bu evden kaçarsin bütün aşiret peşine takllır. Seni de, Azad'i da, Narin'i de öldürürler. O zaman bu ölümü durduramam. Sila - Neden peki? Neden onların hayatları bana bağgll? Neden? Boran - Töre böyle.

Sıla - Nasıl bu kadar sakin bahsedebiliyorsun ölümden?

Boran - Sana daha önce de söyledim. Hepimizin canı töreye bağll. Bundan dönüş yok. (Sıla Boran'ın belindeki silahı kapıp Boran'a doğrultur).

Sila - Peki. (Silahı birden kendine çevirir, Boranın eline tutuşturur) Peki o zaman. Öldür beni. Şimdi öldür. Bitsin bu işkence.

Boran (Silahı elinde sallayarak) - Bu çözüm değil. (Silahı geri beline takar) Sen ölsen de berdel bitmez. Celil'in soyundan başka bir kiz getirirler buraya. Sila - Dilan mı? (Boran başılla onaylar) Bu ne mantıksızlıkya? Bunlar ne biçim töreler? Insan hayatının hiç mi klymeti yok? Böyle yaşanmaz ki.

Boran - Yüzyıllardır böyle yaşadık biz" (S1la, 2006b).

Sıla'nın bu diyalogda söylemiş olduğu "Bu ne biçim töreler? İnsan hayatının hiç mi kıymeti yok?" sözleri dikkat çekicidir. Unutulmamalıdır ki modern düşünce bireyin toplumsal yaşamdaki önceliğine vurgu yapar. $\mathrm{Bu}$ düşünüş tarzına göre bireyin toplumsal yaşamdaki özerkliği toplumsal yaşam 
için vazgeçilmezdir. Toplumsal yaşam bireylerin özerkliğinin sağlanmasıyla var edilir. Böylelikle sağlanan çoğulcu yapı vasıtasıyla toplum dinamik bir yapı kazanmış olur. Bu yaşam tarzının karşısında yer alan geleneksel yaşam tarzlarıysa bunun tam tersi bir nitelik arz eder. Gelenekçi toplum yapıları herkesin üzerinde fikir birliğinin bulunduğu hakikatler vasıtasıyla işler. Böylesi bir yaşama evreninde bireyin arzuları, erekleri, ihtiyaçları ikinci planda yer alır. $\mathrm{Bu}$ anlamda yaşamında ilk defa gelenekçi bir yaşama evreninin davranış kalıplarıyla karşı karşıya kalan Sıla'nın yaşamış olduğu şaşkınlık çarpıcıdır. Bizlere dizide birbirinden tamamen farklı iki ayrı yaşama evreni sunulmaktadır. Bu yaşama evrenleri birbirinden öylesine ayrıdır ki, birbirlerinin dil evrenini dahi anlayamazlar. İçinde yaşamaya alışmış oldukları dünyaların birbirinden tamamen farklı olduklarına dair yapılan vurgu, şu diyalogda daha da belirgin bir biçimde ortaya çıkar:

"Boran - Sila. Hadi kalk artık geç oldu.

Sıla - Ben böyle iyiyim, gelmeyeceğim. (Arkasını döner, yürür)

Boran - Bir kere de dik başlılik etme.

Sila - Gelmek istemiyorum. Ne o? Gece vakti bahçede tek başına oturanları da mı öldürüyorsunuz? Töreleriniz öyle mi söylüyor?

Boran - Ne diyorsun sen Sila? (Kolundan tutar çevirir)

Sila - Birak kolumu.

Boran - Üşüyeceksin.

Sıla - Sana ne üşümemden? Bırak kolumu (Kolunu çeker)

Boran (Yine tutar) - Sila!

Sıla - Bırak kolumu avazım çıktığı kadar bă̆ırırım.

Boran-Bă̆ırma. Bağırma.

Sila (Bağırmaya başlar) - Bırak kolumu!

Boran - Bă̆ırma dedim. Bă̆ırma. (Eliyle ăgzını kapatır) Bağırma. Bağırma. Dur. (Fısıldayarak) Bă̆ırma (Çekiştirerek içeri götürür). Sus! Bă̆ırma. Sus artık. Sus. Zaten zor inandırdım bugün onları. Şansinı fazla zorlama.

Durumun hassasiyetinin farkında değil misin? Senin yaşadığın yerde her şey farklı olabilir. Ama bu evde benim kurallarıma uyacaksın. Ailem, aşiretim bizi karı koca biliyor. Bu oyunu oynayacağız. Başka yolu yok.

Sila - Bunu asla yapmayacă̆ım" (S1la, 2006b).

$\mathrm{Bu}$ diyalogda sağlıklı bir iletişim için gerekli olan uzlaşmacı dilden eser yoktur. S1la "Gece vakti bahçede tek başına oturanları da mı öldürüyorsunuz? Töreleriniz öyle mi söylüyor?" diyerek Boran'ın çok değer verdiği töreleri ağır bir dille eleştirmektedir. Boran ise Sıla'nın geldiği dünyanın farklı bir dünya olduğunu "Senin yaşadığın yerde her şey farklı olabilir" diyerek vurgulamakta ve Sıla'yı kendi dünyasının kurallarına uymaya zorlamaktadır. Bunların yanı sıra, diyalogda gelenekçi yaşama 
evreninin sürekli olarak olumsuzlanıyor olması bir diğer dikkat çekici olgudur.

Dördüncü ve beşinci bölümlerde ise S1la'nın yaşamakta olduğu trajediler devam eder. Sıla'yı evlatlık edinen ailesi, kendisini Mardin'de ziyaret ettikten sonra, İstanbul'a dönerken geçirdikleri trafik kazasında hayatlarını kaybederler. $\mathrm{Bu}$ durum karşısında Sıla kendisini dünyada yapayalnız hissetmeye başlar. Daha önce hiç deneyimlememiş olduğu "çaresizlik" hissine kapılır. Tek arzusu kaybettiği ailesini tekrar görebilmektir. Boran, Sıla'nın bu arzusunu anlayışla karşılar. Hastaneye Sıla ile birlikte giden Boran, burada cenazeleri teslim almak için Mardin'de bulunan Burhan'la (Tarık Şerbetçioğlu) karşılaşır. Burhan, tüm yaşanan olumsuzluklardan Sila'yı sorumlu tutmaktadır. Sila'nın İstanbul'daki tüm yakınlarının aynı kızgınlığı paylaştığını düşünen Boran, Sıla'yla İstanbul'daki cenaze törenine gitmenin tatsız sonuçlar doğuracağını düşünür. Hâlbuki Sıla'ya İstanbul'a birlikte gideceklerine söz vermiştir. Bir şekilde İstanbul'a gitmeye kararlı olan Sıla, Boran'ın kötü niyetli olduğunu düşünmeye başalar. Boran, her ne kadar tamamen iyi niyetli olsa da, Sıla'y1 buna inandıramaz. Boran'a nefreti hızla artan Sıla, bir çıkış yolu arar. Burhan'ın kendisine yardımcı olabileceğini düşünen S1la, çaresizce yardım aramaktadır. Burhan ise Sıla ile tüm bağlarını kopartmakta kararlıdır. Burhan, Boran'a, Sıla'nın kaçmaya çalıştığını söyler. Artık Sıla'yla görüşmek istemediklerini haykıran Boran, Sıla'nın tüm umutlarının yıkılmasına neden olur. Sıla'nın gidecek bir yeri, onu eskiden oluğu gibi kucaklayacak bir yuvası kalmamıştır. Kendisini karşı karşıya kaldığ 1 tüm bu zorluklar karşısında yapayalnız hissetmektedir.

$\mathrm{Bu}$ bölümlerde "gelenekselligin kucaklayıcl ve bireyin kendisini güvende hissetmesini sağlayıcı özellikleri” vurgulanır. Boran her şeye karşın güvenilir ve mert biri olarak bizlere sunulur. Burhan ise modern dünyanın "güvenilmez," "içen pazarlıkll" ve "çıkarı için her şeyi yapabilecek" bencil karakterini temsil etmektedir. Hiç kuşkusuz ki, modern yaşam bireye kendisini gerçekleştirebilmesi için pek çok olanak sunmaktadır. Kişinin özel alanı ile kamusal alan arasında yapılan keskin ayrım, kişinin özgünlügünü sağlayabilmesini temin eder. Ancak, bunun yanı sıra, modern yaşamda kişi, toplumsal yaşam bağlarından kopartılabilmektedir. Modern bireyin diğer bireylerle girdiği ilişkilerde geleneksel kuralların ve ahlak ilkelerinin varlı̆̆ının ortadan kalkmasıyla birlikte, toplumsal yaşam bir varoluş savaşının sahasına dönüşmektedir. Bu durum modern kent kurgusunda da karşımıza çıkmaktadır. Modern yaşamın varlık alanı olan modern kentler bireylerin yoğun bir mücadele içinde oldukları ve kendilerini sürekli olarak yalnız hissettikleri mekânlardır. İşte bu modern kentin var etmiş olduğu 
Burhan sevgi, bağlılık, emek gibi değerleri bir anda kenara itebilmekte ve S1la'yı tüm çaresizliği ile yüzüstü bırakabilmektedir.

Konaktaki yaşama alışmaya ve ailesini kaybetmiş olmanın sebep olduğu yalnızlık hissini yenmeye çalışan Sıla, Emre'den (Kartal Balaban) İstanbul'daki ailesinin tüm miraslarını kendisine bıraktıklarını öğrenir. Sıla büyük bir şaşkınlığa kapılır. Artık Sıla, Türkiye'nin sayılı zenginlerinden biridir. S1la geleneklerin kurbanı olmaktan bu sayede kurtulabileceğini düşünür. Bir anda, "modern yaşamın getirmiş olduğu olanakların, Stla'ya gelenekler karşısında bir avantaj sağlayıp sağlayamayacă̆g," dizinin temel sorunsalı olarak karşımıza çıkar. Bu sırada Emre ile Sıla'nın ilişkisini çözmekte zorluk çeken Boran, onların yakınlıklarından rahatsız olur. Bunun üzerine Boran, Emre'yi uyarmaya karar verir. Ona kendisine ait olan her şeyden uzak durmasını söyler ve onu tehdit eder. Bunun üzerine Sıla ile Boran arasında şu diyalog yaşanır:

“Boran (Hışımla üstüne yürüyüp yumruğunu kaldırır) - Bak hala! (Abay araya girip kolunu tutar. Emre sinirle çıkar) Bir daha bu adam evime adımını atmayacak. (Sıla'ya parmağını sallayarak) Sen de onunla görüşmeyeceksin.

Sıla - Sen bana ne yapıp ne yapamayacă̆ımı söyleyemezsin Boran ă̆a. Ben senin kölen değilim. Hatta ben senin hiçbir şeyin değilim.

Boran (Stla'y iki kolundan tutarak) - Bana bak! Sen Genco aşiretinin gelinisin. Ona göre davranmak zorundasin. Sana kalan paraya da bel bağlama. Törelerden daha güçlü olamazsın. Törelerin önüne geçemezsin. Ben de kan dökülmemesi için sonuna kadar töreleri kollayacağım.

Sila - Emin ol ömür boyu burada kalmayacağım Boran. Emin ol. (Boran onu yana savurur, Sila yukarl çıkar).

Boran - Aziz! Haydar! (Korumalar koşarak gelir) Bundan sonra bu kapıdan benden habersiz kimse girmeyecek, kimse çıkmayacak. Bana danışılmadan kuş uçmayacak. Anlaşıldı mı? Bu kapının kilidi bundan sonra benim sözümdür. (Sıla balkondan bakmaktadır) Buna uymayan töreye başkaldırmış olur. O İstanbul züppesini de bulup haddini bildirin (Sıla aşă̆ inmeye başlar).

Şivan Kâhya - İcabına bakalım mı ăgam?

Sıla (Koşarak aşağı inmektedir) - Sen ne yapıyorsun ha? Ne yaptı̆̆ını zannediyorsun hayvan herif! (Boran'in üstüne atılip vurmaya başlar, korumalar arkalarını dönüp biraz uzaklaşır) Ne yaptığını zannediyorsun? Hayvan misin?

Boran (Kollarını tutarak) - Sila benim işime karışma artık.

Sıla - Ya, işine karışmayayım da Emre'yi öldür değil mi? Çabuk söyle o adamlarına, çabuk söyle Emre'nin kllına bile zarar vermesinler. Çabuk söyle. 
D. Özkan / Kültürel Bir Gösterge Olarak Gelenek ve Modernlik İkilemi: "Sila” Televizyon Dizisi

Boran - Sila! Odana!

Sila (Kolunu kurtarır) - Gitmeyeceğim ha gitmeyeceğim.

Boran - Sila odana çık.

Sila - Odama gitmezsem ne yaparsın? Beni de mi öldürürsün hayvan herif?

(Boran tokatlayacakmış gibi elini kaldırır ama yapamaz) Vursana. Bir yapmadı̆̆ın o kaldı ha. Sen o tokadı attın Boran. Elini kaldırdı̆̆ın an o tokadı attın. (Adamlar kavganın bitmesini bekleyip dişarı çıkarlar)

Boran - Bana bak. (Kolundan tutar) Bir daha benim adamlarımın yanında sakın bana bağırma Sıla. Sakın!

Abay (Tayanç Ayaydın) - Boran. (Sıla'nın yanına gelir) Yenge iyi misin sen? Sila - Bana bak Boran ăga. Emre'nin kılına bile zarar gelirse kendimi öldürürüm. Yemin ederim ki kendimi öldürürüm! (S1la, 2006c).

Diyalog boyunca farklılıkların vurgulanıyor olması dikkat çekicidir. Farklı kültürel yapılar söylemler aracılığıyla sunulmaktadır. Farklılıklara ağırlıklı bir vurgu yapılması vasıtasıyla ayrımların netleştirilmesi amaçlanmaktadır. Geleneksel olanın modernlik içinde barındırılamayacağı vurgulanarak gelenekselin aşılması gereken bir duruma tekabül ettiği iletilmektedir. Bu sayede, geleneğin, sadece, modern olanın çok uzağında yer alan kendi topraklarında ifadesini bulabileceğine dikkat çekilmektedir.

Daha sonraki süreçte Sıla, Narin'le sohbet ederken Boran'ın daha önce Yezda (Leyla Başak) ile yaşadıkları aşkı ve hazin sonunu öğrenir. Bu durum Sıla'nın Boran'a olan bakışını değiştirir. Aralarında kıskançlıkla karışık yeni bir yakınlaşma başlar. Dizide, Boran'ın gelenekleri ile Sıla arasında sıkışıp kalmış hali, sürekli vurgulanmaktadır. Bu vurgu özellikle yedinci bölümde daha net bir biçimde karşımıza çıkmaktadır. Yedinci bölümün başında da Boran’ın Sıla'yı Emre'den kıskanıyor olması işlenir. Emre'yle Sıla'nın aralarında yaşananları sürekli olarak düşünen Boran sağduyusunu kaybeder. Sıla artık kendisini tutsak gibi hissetmektedir. Boran'ın kaba davranışlarından son derece rahatsız olan Sıla'nın geleneklere nefreti büyümektedir. Bu arada Boran bir yandan Sila'nın huzursuzluklarını gidermeye, diğer yandan aşiretin kan davasını durdurmaya çalışmaktadır. Üstelik her iki durum içinde arzuladığı sonucu elde edememektedir. Sonuç olarak, bölüm boyunca, Boran'ın, gelenekleri ve aşiretiyle ile Sila arasında sürekli bocalaması işlenmektedir. Boran'ın mutlu olabilmesinin önündeki en büyük engel, içinde bulunduğu arada kalmışlık hali olarak sunulmaktadır (S1la, 2006d).

Dizide geleneksel yaşam kalıplarının Boran ve Sıla'nın mutluluklarının önündeki en büyük engel olarak tasvir edilmesi problemimiz açısından son derece önemlidir. Dizideki diyalogların içeriği, özü itibarıyla aydınlanmacılığa tekabül etmektedir. Daha önce de belirtildiği üzere aydınlanma fikriyatı kendisinden önceki dönemi "ortaçă̆ karanlı̆̆ 
ifade etmiştir. Böylelikle, geçmiş çağlara ait tüm değerler toplumsal hayatın dışında konumlandırılmıştır. Mutlu olabilmek için ilerlemeye ve çağdaşlaşma ihtiyaç duyulduğunu vurgulayan modernist kavrayış, Sıla dizisindeki diyaloglarda siklıkla gözlemlenmektedir. Tüm bu söylenilenlerden hareketle, Sila dizisinde ki iletişimsel işleyişe dair kategorileri "söylenen şeye ilişkin kategoriler" ve "söyleme tarzlyla ilgili kategoriler" olarak iki alt başlıkta inceleyebiliriz.

\subsection{Söylenen şeye iliş̧kin kategoriler \\ 3.2.1. Illetişimin Konusu}

Dizide var olan aktörlerin aralarında gerçekleşen diyalogların, esas itibarıyla, geleneksek yaşam tarzı ile modern yaşam tarzı arasında gerçekleşen gerilimi, konu edindiği gözlemlenmektedir. Örneğin, bu tema açısından, dokuzuncu bölümde gerçekleşen şu diyalog dikkat çekicidir:

”Sıla - Boran. Boran. Ne yapacağız? Zeyşan’ ı böyle kaderine mi birakacağız?

Boran - Nikâh kıyıldı Sila. Artık yapacak bir şey yok.

Sila - Öldürdünüz onu.

Boran - Onun hayatta kalabilmesinin tek yolu buydu Sila. Töre başka yol tanımiyordu.

Sıla - Aynı beni öldürdü̆g̈ün̈z gibi öldürdünӥz onu.

Boran - Ben bu olanlardan mutluyum mu saniyorsun Sila? Ben de seninle evlenmek istemedim. Ama kardeşimin canı için buna mecburdum. Burada katı kurallar var. Bunları hemen yıkamazsın. Ben onları yaşanır hale getirmeye çalışlyorum. Ama sen benle her savaşında işleri daha da zorlaştırtyorsun...

Sila - Benim seninle bir savaşım yok Boran. Hatta artık burasıyla da yok. Tek bildiğim burası bir cehennem.

Boran - Sana kimse cennet vaat edemez. Sen kendin bulacaksin cenneti. Ben seni çok daha güçlü biri sanmıştım. Ama yanılmışım maalesef”' (S1la, 2006e).

$\mathrm{Bu}$ diyalogda gerçekleşen iletişimin konusu geleneklerin acımasızlığı olarak belirtilebilir. Modern yaşamda yetişmiş Sıla'nın gelenekler karşısında hissetmiş olduğu ürküntü diyalog boyunca dikkat çekici bir biçimde işlenmektedir. En dikkat çekici olgu ise diyalogda yörenin en güçlü insanı olan Boran ağanın dahi gelenekler karşısında kendisini çaresiz hissetmesidir. 
D. Özkan / Kültürel Bir Gösterge Olarak Gelenek ve Modernlik İkilemi: "Sıla" Televizyon Dizisi

\subsubsection{Illetişimin Yönü (Lehte veya Aleyhte, Taraftar veya Karşıt)}

Geleneksel yaşamın kuralarını ifade eden gelenekler dizi kahramanlarının mutluluğunun önünde en büyük engeli teşkil ettiği gözlemlenmektedir. Dizi kahramanları mutluluğa kavuşma çabası içindedirler. Ancak gelenekler sürekli olarak karşılarına çıkmaktadır ve mutluluğa ulaşmalarını engellemektedir. Bu manada gelenek karşıtlığı dizide sıklıkla vurgulanan bir temadır. Örneğin üçüncü bölümde Narin babasına (Namık Kemal Yiğittürk) şunları söylemektedir:

"Narin - Baba! Benden yüz çevirecek kadar kötü ne yaptım baba? Biz Azad'la sevdamizın peşinden gittik. Namusumuza halel getirecek hiçbir şey yapmadık. Şimdi sevmenin sonu ölüm? Madem bu kadar kararlısınız bizi öldürmeye sevdamızın bitmeyeceğini bilin isterim. Unutmayın hükmünüz bedenimizedir sadece"'(S1la, 2006b).

Narin'in bu söylediklerinden de anlaşılacağı üzere geleneklerin adaletsizliği ve insan yaşamına olan duyarsızlığı vurgulanmaktadır. Geleneklerin sevenlere verdiği hüküm ölümdür. Gelenekler bir babanın kızının duygu ve düşüncelerine karşı duyarsızlaşmasına yol açmaktadır. İnsanların mutlu olabilmesinin yolunun geleneklerin aşılması ve yaşamdan soyutlanması olduğu da sıklıkla işlenmektedir.

\subsubsection{Işslenen Değerler, Amaçlar ve Arzular}

Dizi kahramanlarının amaçlarının sevdikleriyle birlikte mutluluğa kavuşmak olduğu söylenebilir. Bu amaçlarına ulaşma çabası içindeki dizi kahramanları, sürekli olarak geleneksel yaşamın kurallarını ifade eden gelenekler ile modern yaşamın yeni değerleri arasında bocalamaktadır. Dizi kahramanları, bir tercihte bulunmaları gerektiğinde, derin sıkıntı ve kararsızlıklar yaşamaktadır. İşte bu noktada dizide işlenen değerler ön plana çıkmaktadır. Dizide genel itibariyle geleneksel yaşamın değerleriyle modern yaşamın değerleri karşıt ikilikler olarak sunulmaktadır. Bu çerçevede geleneksel değerlerin aşiret olarak ifade edilen klan yapısının ihtiyaçlarını ve arzularını gidermek için inşa edilmiş olan kurallar olduğu açık bir biçimde gözlemlenmektedir. Modern yaşamın kurallarının ise bireyin amaçlarını ve arzularını tatmin etmek için düzenlendiği ve modern hukuk sistemiyle güvenceye alındığı gözlemlenmektedir. Zira geleneğin işleyişi ("yaptığ edimlerden dolayı ölümle cezalandırma," "zorla evlendirme" v.b. gibi) modern hukukun ihlali vasitasılyla gerçekleşebilmektedir.

\subsubsection{Amaçlara Ulaşmada Başvurulan Yollar}

Geleneklerin baskıcı özelliği sürekli işlenen başlıklardandır. $\mathrm{Bu}$ baskıcı yapı karşısında bireyler büyük bir korkuyu paylaşmaktadır. Bu 
korkulardan dolayı, dizinin kahramanları, baskı altında olmanın psikolojisini ifade eden kaçma, yalan söyleme, entrikalar tasarlamak gibi hileli yollara başvurmaktadır.

\subsubsection{Kişileri Betimlemekte Kullanılan Çizgiler}

Geleneksel yaşamın karakterlerini ifade eden Boran, Cihan v.b. gibi karakterlerin sürekli "kirli sakallı" olarak resmedilmeleri dikkat çekicidir. Hiç kuşkusuz ki, dizide Boran ağa etkileyici bir karakter olarak sunulmaktadır. Ancak onun etkileyiciliği geleneklerle olan mücadelesinde anlam kazanmaktadır. O geleneklerin mutlu olmasına izin vermediği ve gelenekleri aşmaya çalışan bir kahramandır.

\subsubsection{Olayların Geçtiği Yerler}

Dizide gerçekleşen olaylar Mardin ve İstanbul'da gerçekleşmektedir. Mardin geleneksel yaşama evreninin görsel sahasıdır. İstanbul ise modern yaşamın yaşama evrenini temsil etmektedir. Bu çerçeveden bakıldığında Mardin, etkileyici binaların bulunduğu nostaljik bir görsel şölen ile sunulmaktadır. Ancak dizide Sıla'nın tutsak olduğu ve kendisini hapishanede hissettiği konakta ifade edilen bu geleneksel evren, aynı şekilde bireyi baskı altına alan ve onu geleneklerin belirleyiciliğine tabi kılan bir mekândır. İstanbul ise özellikle Sıla'nın Mardin'den kaçtığı ve on sekizinci bölümde doruk noktasına ulaşan bir takip sürecini yaşamak zorunda kaldığı bir mekândır. Birey modern sistemin sağladığ güvenceler sayesinde kendisini daha iyi ifade edebilme imkânına işte bu modern yaşama evreninde sahip olmaktadır.

\subsection{7. Çatıșma Kaynakları ve Konuları}

Dizi kahramanları hem birbirleriyle hem de geleneksel değerlerle çıkara endeksli (iyi/kötü bağlamında) bir çatışmanın içerisindedir. Yukarıda da ifade ettiğimiz gibi bir arada kalmışlık durumundan kaynaklı olarak ortaya çıkan çatışmalar çeşitli varyasyonlarla ortaya çıkmaktadır. Yaşanan çatışmaların, geleneklerden kaynaklı olarak, kişilerin yaşamlarını arzu ettikleri bir biçimde sürdürememelerinin "doğal" bir neticesi biçiminde ortaya çıkması dikkat çekicidir. 
D. Özkan / Kültürel Bir Gösterge Olarak Gelenek ve Modernlik İkilemi: "Sıla” Televizyon Dizisi

\subsection{Söyleme Tarzlyla İlgili Kategoriler}

\subsubsection{Iletişimin Tipi ve Yapısı}

Dizide kahramanların arasında gerçekleşen iletişimsel etkinliklerin genel karakteri iletişimin genel karakter ve yapısının çözümlenebilmesini sağlamaktadır. Kişilerin geleneklerden dolayı, sürekli baskı altında olmaları ve gerek geleneklerle, gerekse birbirleriyle çatışmalar yaşamaları diyaloglarının içeriğine yansımaktadır. $\mathrm{Bu}$ durum "gergin" olarak nitelendirilebilecek bir iletişim ortamının oluşmasına sebep olmaktadır. Aynı zamanda gelenekler karşısında çaresiz duruma düşmüş olmaktan kaynaklı olarak ortaya çıkan bir içerik ile de karşı karşıya kalmaktayız. Aşağıda Abay ile Boran arasında gerçekleşen diyalog bunun önemli bir örneğidir:

"Boran - Klzın evleneceğinden haberi yokmuş Abay.

Abay - Ne?

Boran - Yokmuş işte. Ailesi kızı kandırmış.

Abay - Eee?

Boran - Bütün gece kuş gibi çırpındı durdu. Ama yapacak bir şey yok. Ben vazgeçsem büyüklerimize söz geçmez.

Abay - Ne demek yapacak bir şey yok? Ă̆zından çıkanı kulağın duyuyor? ... Bak. Yaranı deşmek istemem ama Yezda da bu töreler yüzünden kıymadı mı canına? Sana bir evlat veremediği için kendinde buldu kusuru. Şimdi de bu klz yanmasin.

Boran - Bir şey yapamam.

Abay - Boran sen ă̆asın. Al götür onu. O senin topraklarına alı̧̧amaz. Ama belki sen onun topraklarına alışabilirsin. Sen ki kuşların dilinden anlarsin Boran. Bırak kuşu kafesinden uçsun. Sen de onun yanında uç. Belki böyle kazanirsın onu. Ama burada imkânsız. Boran götür onu” (S1la, 2006a).

Bu replikte de Boran'ın, ağa olmasına rağmen, gelenekler karşısında çaresiz kalışı açık bir biçimde vurgulanmaktadır. O gelenekler karşısında sadece bir uygulayıcı olarak işlev üstlenmektedir. Bu durum birey üzerinde şiddetli bir baskının doğmasına sebep olmaktadır. Bu ise iletişimin çatışmacı bir yapı arz etmesine yol açmaktadır. 12. Bölümde de aşiret üyeleri ile Firuz Ağa (Muhammed Cangören) arasında geçen diyalog geleneksel yaşamın egemen olduğu toplum yapılarında kişilerin ne derece törelerin esiri olduğunu göstermeye çalışan bir diğer örnektir.

Aşiret üyesi - Biz ki canımızı, malımızı, geçmişimizi ve hatta geleceğimizi Boran Ağaya emanet etmişken onun karısına, bacısına sahip çıkamaması ona hiç yakışmamıştır.

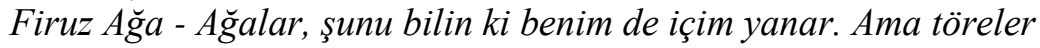
karşısında ăga da olsam, oğlum ve kizım için herhangi bir kayrllma beklemiyorum. Töreler neyi uygun görüyorsa o uygulanacaktır. Biz Celil 
Efendi'ye konuştuk. Hükmümüzü kendisine bildirdik. O üzerine düşeni yapacaktır.

Celil (Ă̆layarak) - Töreler karşısında boynum kıldan incedir ă̆am. Aşiret üyesi - Peki onların kaçmasına yardımcı olan o İstanbullu, onun canını Celil Efendi mi alacak?

Bir başka aşiret üyesi - Aşiretimiz karar verdi. Onun canını almak Boran ăgaya uygundur (S1la, 2006f).

\subsubsection{Kullanılan Retoriğin Yöntemi}

Repliklerde genel olarak "ikna edici" bir eletişim yöntemine rastlanmadığ 1 gözlemlenmektedir. "Zorlama" ve "tehdit" gibi diyalojik bir iletişimde bulunmaması gereken olgulara ise sıklıkla rastlanmaktadır. $\mathrm{Bu}$ sayede bireyler belirli davranışları sergilemek zorunda bırakılmaktadır. Daha önce de değindiğimiz aşağıdaki diyalog bu tarz bir retoriğin en dikkat çekici göstergelerini içermektedir:

\section{"Sıla - Neden peki? Neden onların hayatları bana bağhl? Neden?} Boran - Töre böyle.

Sila - Nasıl bu kadar sakin bahsedebiliyorsun ölümden?” (S1la, 2006b).

$\mathrm{Bu}$ replikte de görüldüğ̈̈ üzere töreler ve ölümle tehdit etmek sürekli karşımıza çıkan bir olgudur. Üstelik burada da gözlemlenebileceği üzere tehditte bulunan kişi çoğu zaman gelenekler karşısında kendisinin de çaresiz kaldığını ve sadece gelenekleri uygulamakla mükellef olduğunu vurgulamaktadır. S1la bu replikte modern bir bakış açısı ile süreci sorgulama çabasındadır. Bu sebepten dolayı da "Neden?" sorusunu sormaktadır. Ancak Boran'dan almış olduğu "Töre böyle" cevabı son derece sarsıcıdır. Töre böylelikle ile söylemin genel retoriği içerisinde "sorgulanamaz" bir konuma yerleştirilmektedir. Boran'ın ölümden ve geleneklerin sorgulanamazlığından bu derece sakin bir biçimde bahsedebiliyor olması Sıla için inanılamaz bir durumdur. Zira modern yaşam bireyin arzularını öncelikli olarak gözetmektedir. Modern bir yaşamdan gelmiş olan Sıla'da doğal olarak bireyin bu derece belirlenimlere tabi kılınması karşısında dehşete düşmektedir. Ancak, yaşamında, geleneklere başat bir rol atfeden Boran için aynı durum söz konusu değildir. Dolayısıyla da geleneklerin yerine getirilebilmesi için gerekli olan her şeyi yapma konusunda tereddütsüz davranabilmektedir. Onun kullanmış olduğu retorik, bu sebepten dolayı, "zorlama" ve "tehdit" vasıtasıyla işlemektedir.

Toplumlar geçiş dönemlerinde önemli ikilemler ile karşılaşabilmektedir. Geçmişin alışkanlıkları ve kuralları ile yeni koşulların uyuşmadığı durumlar kişilerin çeşitli kimlik problemleri yaşamalarına neden olabilmektedir. Geleneksel yaşam kalıplarının, modernlik koşullarında 
oldukları gibi sürdürülebilmeleri mümkün değildir. Yaşamın, insan ihtiyaçlarının ve taleplerin dönüşmesi kural ve gayelerin değişmesine neden olur. Ancak, geçmişin ve geleneğin "ötekileştirilerek" sağlılı bir toplumsal değişimin temin edilmesi mümkün değildir.

Özellikle geleneksel yaşamın egemen olduğu bölgelerde törelerin pek çok mağduriyetlere neden olduğu aşikârdır. Geleneksellikten modernliğe geçişin bedelini bireyselleşme sürecindeki çok sayıda genç ödemiştir. Bağlı (2004: 38), toplumsal değişmeye karşı direncin, toplumsal değerlerin belirleyici olduğu organik toplumlarda, güçlü olduğunu belirtir. Ona göre değişimin kaçınılmaz bir süreç olduğu bilinse de, değişimin genel toplumsal yapıyla uyumlu olmadığı koşullarda patolojik durumların ortaya çıkması kaçınılmazdır. Geç modernleşmiş toplumlardaki modernleşme süreçlerinde modernleşmeyi arzu eden özne, grup ve sınıflar ile gelenekçi komüniteler arasında ciddi söylem farklılaşmalarının ortaya çıkması sıklıkla gözlemlenen bir olgudur. Politika sahasında ciddi gerilimlere kapı açacak olan bu tür söylem farklılıkları, "ötekileştirici" nitelikler arz ettiğinde, toplumsal problemlerin çözüme kavuşturulmasını engelleyebilmektedir. $\mathrm{Bu}$ nedenle, farklı politika ve yaşam tarzına sahip olan öznelerin diyalojik demokrasinin ilkelerine uygun bir biçimde, toplumsal hayatın sürdürülebilirliği için vaz geçilmez olan "karşıllıkl bilgi"nin (mutual knowledge) eşgüdüm inşa sürecine katılmaları gerekir.

\section{Sonuç}

Türkiye toplumu, özellikle son yüz yıllık dönemde yaşamakta olduğu kültürel dönüşümlerin yol açtı̆ğ açmazlarla karşı karşıyadır. Bu süreçte, Cumhuriyet ile birlikte bir proje olarak gerçekleştirilmeye çalışılan modernleşme ve batılı toplumların yapısal nitelikleri, tam manası ile inşa edilememiştir. Bunun yanı sıra, modernist söylemin 1srarla geleneksel değerlerin kamusal yaşamdan soyutlanması gerektiğine dair geliştirmiş olduğu çeşitli içerikler, toplumsal hayatta dolaşıma girme olanağına kavuşmuştur. Bu sayede çok sayıdaki politik ve ideolojik içeriği barındıran kültürel gösterge, medyadaki eserler vasıtasıyla günlük yaşamın bir parçası haline gelmiştir. Bu manada, Sila dizisinde geleneksel yaşamın mutluluğun önünde bir engel olarak gösterilmesi anlamlıdır. Dizideki diyaloglarda geleneksel değerlerin bireyin özgürlüklerini ve yaşamını tehdit ettiği, sıklıkla, işlenmektedir. Otuz beşinci bölümden itibaren Boran ağa, Sıla'ya karşı modern yaşam kalıplarına uygun davranmaya başladıkça çiftin daha mutlu olmaya başladığı gözlemlenmektedir (Sıla, 2007). Çiftin mutluluğa, geleneksel değerler yerine modern değerleri benimsemeye başladıkları bir süreçte kavuşmaları, modernliğin insanlık için vazgeçilemez olan üstün 
değerlere sahip olduğunu vurgulamak için seçilmiş bir mesaj olarak değerlendirilebilir.

Küçükömer (1969: 95), Türkiye’deki Batılılaşma çabalarını “sözde bir kültür devrimi” olarak nitelendirmektedir. Sıla dizisinde de gerek içerik ile ilgili alanda, gerekse görsel alanda çeşitli kültürel göstergeler ön palana çıkartılmıştır. Her iki alanda, geleneği temsil eden "doğu," dönüştürülmesi ve elimine edilmesi gereken geleneğin kaynağı olarak sunulmaktadır. Sıla dizisinde, geleneğin bireye acı veren niteliklerine yapılan vurgu, Türk modernleşme söylemiyle uyum içerisindedir.

Bayram ve Çınar (2007: 12-13), dünyanın rasyonel bir biçimde tasarlanmasının modernliğin arka planını oluşturan başlıca niteliği olduğunu belirttikten sonra, modernlik koşullarında bürokrasinin toplumsal örgütlenmeyi sağlayan başlıca faktör haline gelmesinin şaşırtıcı olmadığını vurgular. Türkiye'de de devlet bürokrasinin ideoloji ve eğilimleri tüm kamusal alanda yansımalarını bulmaktadır. Karakaş (2002: 156) günümüzde, ortaya çıkmış olan yeni gelişmelerle birlikte politik iktidarların yeni olanaklara kavuştuğuna dikkat çeker. Bu olanakların en önemlilerinden biri olan medya, devletin ideolojik bir aygitı olarak, toplumun şekillendirilmesinde etkili bir güçtür. Medyadaki eserlerde sunulan diyalog içeriklerinin, öncelikle devletin modernleştirilmesi için başlatılan bir "proje" olarak biçimlenen batılılaşmacı (veya modernist) dünya görüşlerinden izler taşıması şaşırtıcı değildir. Sıla dizisi gibi örneklerde ise, bir adım öteye gidilerek, geleneksel yaşam dünyaları yabancılaştırılarak, oryantalist bir söylem ile sunulmaktadir.

Televizyon vasıtasıyla, kolektif bellekteki "karşılıklı bilgi” yapılarını biçimlendiren iktidar, toplumu şekillendirmek ve yönlendirmek için önemli olanaklar elde etmektedir. Çağımızda, ağırlıklı olarak, "gazete okumak," "eğlence programlarını takip etmek," "sosyal medyay kullanmak" ve "televizyon izlemek"ten oluşan malumat edinimi (Meulemann, 2012: 186), kişilerin yaşamlarını, beğenilerini ve dünya görüşlerini biçimlendirmekte kullandıkları başlıca faaliyettir. Daha öncede belirtildiği gibi, televizyon toplumun tarihle bağlarını kopartan bir işleve sahiptir. Zira televizyon programlarında, tarihsel bir temele dayalı olan geleneksel yaşamın tasvirleri günümüzün ihtiyaçlarından hareket edilerek yeniden yapılandırılmaktadır. $\mathrm{Bu}$ sayede, bireyin bakış acısını bugün ve gelecekle sınırlandıran bir dünya görüşü ve ideolojinin gelişebilmesi mümkün olmaktadır. Hâlbuki insan belirli bir geleneğin içine doğar. Var olma sürecini devam ettirdiği bu gelenek, insanın hayat serüveninde belirleyici bir role sahiptir. Gelenek ve tarihle bağları kopartılan birey, toplumda kendi amaç ve arzularını toplumsal olanla uyumlu kılmak gibi bir çaba göstermemektedir. Toplumsal yaşam imkânının ortadan kalkmasıyla neticelenecek olan böylesi bir süreçte, 
D. Özkan / Kültürel Bir Gösterge Olarak Gelenek ve Modernlik İkilemi: "Sıla" Televizyon Dizisi

televizyonun sahip olduğu işlev, diğer kitle iletişim araçlarıyla karşılaştırıldığında, belirleyici bir özellik arz etmektedir. Haftalarca süren televizyon dizilerinin, televizyonun toplumu gelenekten yalıtma işlevini edinebildiği, Sıla dizisi örneğinde, net bir biçimde, gözlemlenmektedir.

İzleyicilere sürekli tekrarlanarak sunulan mesajların, refleksif (reflexive) bir biçimde değerlendirmesi mümkün değildir. Öyle ki, televizyonda sunulan görsel dünya gerçeklik ile aynı şey olarak algılanabilmektedir. Oysaki kamusal alanda önemli pek çok işlevi yerine getiren medyanın, toplumun kanaatlerinin oluşumunda belirleyici olmaması gerekir. Medya kanaatlerin oluşması için gerekli olan verileri mümkün olduğunca gerçeğe yakın bir biçimde kamuoyunun bilgisine sunmalıdır. Eğer ki, medya, kanaatlerin oluşumunda "yönlendirici" bir işlev yüklenirse, incelemiş olduğumuz Slla dizisi örneğinde de görüldüğü üzere, çok sayıda örtülü politik ve ideolojik içeriğin taşıyıcısı haline gelir. Bu durum, diyalojik demokrasinin gerçekleşme imkânının ortadan kalmasına neden olacak neticelere yol açabilecek potansiyele sahiptir.

\section{Kaynakça}

Bağl1, M. 2004. Batman İntiharları Bağlamında Özgürlüğün ve Geleneksel Toplumsal Yapının Kentsel Kurgusu, Ankara Üniversitesi Psikiyatrik Kriz Uygulama ve Araştırma Merkezi, Kriz Dergisi, Cilt 12, Say1 1, 21-40.

Baudrillard, J. 2004. Tam Ekran, (Çev.) B. Gülmez, İstanbul: YKY.

Bayram, A. K. ve Çınar, K. 2007. İktidar ve Siyasetin Gölgesinde Bürokrasi ve Demokrasi İlişkisi: İdealler, Zorunluluklar, Gerilimler, Afyon Kocatepe Üniversitesi Sosyal Bilimler Dergisi, Cilt:9, Say 1:1, 11-24.

Bilgin, N. 2000. İçerik Analizi, İzmir: Ege Üniversitesi Edebiyat Fakültesi Yayınları.

Blommaert, J. ve Bulcaen, C. 2000. Critical Discourse Analysis, Annual Review of Anthropology, Vol. 29, 447-466.

Buhara, M. (Senarist), Uslu, Y. \& Oğuz, G. (Yönetmen) 2006a. Sila [Televizyon Dizisi]. Bölüm 2. Atv.

Buhara, M. (Senarist), Uslu, Y. \& Oğuz, G. (Yönetmen) 2006b. Sila [Televizyon Dizisi]. Bölüm 3. Atv.

Buhara, M. (Senarist), Uslu, Y. \& Oğuz, G. (Yönetmen) 2006c. Sila [Televizyon Dizisi]. Bölüm 5. Atv.

Buhara, M. (Senarist), Uslu, Y. \& Oğuz, G. (Yönetmen) 2006d. Sila [Televizyon Dizisi]. Bölüm 7. Atv. 
Buhara, M. (Senarist), Uslu, Y. \& Oğuz, G. (Yönetmen) 2006e. Sıla [Televizyon Dizisi]. Bölüm 9. Atv.

Buhara, M. (Senarist), Uslu, Y. \& Oğuz, G. (Yönetmen) 2006f. S1la [Televizyon Dizisi]. Bölüm 12. Atv.

Buhara, M. (Senarist), Uslu, Y. \& Oğuz, G. (Yönetmen) 2007. Sila [Televizyon Dizisi]. Bölüm 35. Atv.

Çağan, K. 2006. Sanat Sosyolojisinin İmkânına ve İnşasına Dair, Bilgi (13)/2, 11-31.

Daniel J. H. ve King, G. 2010. A Method of Automated Nonparametric Content Analysis for Social Science, American Journal of Political Science. 54(1): 229-247.

Göle, N. 2000. İslam ve Modernlik Üzerine Melez Desenler, İstanbul: Metis Yayınları.

Kahraman, H. B. 2002. İçselleștirilmiş Açık ve Gizli Oryantalizm ve Kemalizm, Doğu Batı.20-1, 153-180.

Karakaş, M. 2002. İktidar İlişskileri Açısından Bilim ve Sosyoloji, Afyon Kocatepe Üniversitesi Sosyal Bilimler Dergisi, Cilt IV, Sayı 1, s. $163-$ 178.

Köker, L. 2004. Modernleşme, Kemalizm ve Demokrasi, İstanbul: İletişim Yayınları.

Kömeçoğlu, U. 2002. Oryantalizm, Belirsizlik, Tahayyül, 11 Eylül, Doğu Batı, 20-2, 33-50.

Küçükömer, İ. 1969. Düzenin Yabancılaşması, İstanbul: And Yayınları.

Lewis, B. 1980. The Ottoman Empire and Its Aftermath, Journal of Contemporary History, Vol. 15, No. 1, Imperial Hangovers, 27-36.

Lombard, M., Snyder-Duch, J., \& Bracken, C. C. 2002. Content Analysis in Communication: Assessment and Reporting of Intercoder Reliability, Human Communication Research, 28, 587-604.

Mardin, Ş. A. 1969. Power, Civil Society and Culture in the Ottoman Empire, Comparative Studies in Society and History, Vol. 11, No. 3, 258281.

Mardin, Ş. A. 1971. Ideology and Religion in the Turkish Revolution, International Journal of Middle East Studies, Vol. 2, No. 3, 197-211.

McMahon, D. M. 2001. Enemies of the Enlightenment: The French Counter-Enlightenment and the Making of Modernity, Oxford \& New York: Oxford University Press. 
D. Özkan / Kültürel Bir Gösterge Olarak Gelenek ve Modernlik İkilemi: "Sıla" Televizyon Dizisi

Meulemann, H. 2012. Information and Entertainment in European Mass Media Systems: Preferences for and Uses of Television and Newspapers, European Sociological Review, Vol. 28, No. 2, 186-202.

Mutman, M. 2002. Şarkiyatçılık: Kuramsal Bir Not, Doğu Batı.20-2, 105-114.

Postman, N. 2004. Televizyon Öldüren Eğlence, çev. O. Akınhay, İstanbul: Ayrıntı Yayınları.

Purvis, T. ve Hunt, A. 1993. Discourse, Ideology, Discourse, Ideology, Discourse, Ideology, The British Journal of Sociology, Vol. 44, No. 3, 473-499.

Riffe, D., Lacy, S. ve Fico, F. 2005. Analyzing Media Messages: Using Quantitative Content Analysis in Research, New York: Psychology Press.

Yıldırım, Y. 2008. Osmanlı Modernleşmesinde Cemaat-Toplum Yapılaşmas1: Yeni Osmanlı Düşüncesi Örneği, Afyon Kocatepe Üniversitesi Sosyal Bilimler Dergisi, Cilt: X, Sayı 3, 1-22.

Yıldırım, Y. 2012. Neo-Patrimonyalizm Yaklaşımına Karşı Yapılaşma Olarak Türk Modernleşmesi, Afyon Kocatepe Üniversitesi Sosyal Bilimler Dergisi, Cilt XIV Say1 1, 1-21. 